\title{
Ian Geay, De la tombée des nues: une esthétique fin de siècle, «Revue des Sciences humaines», ${ }^{\circ} 289$
}

\section{Ida Merello}

\section{(2) OpenEdition}

1 Journals

\section{Edizione digitale}

URL: http://journals.openedition.org/studifrancesi/8044

DOI: 10.4000/studifrancesi.8044

ISSN: 2421-5856

\section{Editore}

Rosenberg \& Sellier

\section{Edizione cartacea}

Data di pubblicazione: 1 juillet 2009

Paginazione: 432

ISSN: 0039-2944

\section{Notizia bibliografica digitale}

Ida Merello, «lan Geay, De la tombée des nues: une esthétique fin de siècle, «Revue des Sciences

humaines», n²89», Studi Francesi [Online], 158 (LIII | II) | 2009, online dal 30 novembre 2015, consultato il 08 janvier 2021. URL: http://journals.openedition.org/studifrancesi/8044 ; DOI: https:// doi.org/10.4000/studifrancesi.8044

Questo documento è stato generato automaticamente il 8 janvier 2021.

\section{(c) $(1) \ominus$}

Studi Francesi è distribuita con Licenza Creative Commons Attribuzione - Non commerciale - Non opere derivate 4.0 Internazionale. 


\section{Ian Geay, De la tombée des nues: une esthétique fin de siècle, «Revue des Sciences humaines», $\mathrm{n}^{\circ} 289$}

Ida Merello

NOTIZIA

IAN GEAY, De la tombée des nues: une esthétique fin de siècle, «Revue des Sciences humaines», $\mathrm{n}^{\circ} 289$, janvier-mars 2008, pp. 139-152.

1 L'A. isola nell'estetica decadente il topos della caduta al suolo, in cui intravede anche il feticismo della rappresentazione della vittima e l'esorcizzazione del corpo della femme fatale, che smette così di impaurire l'uomo. Allo stesso modo lo stupro è un rovesciamento dialettico della minaccia del corpo femminile, che diventa un fatto estetico nella sua traduzione in scrittura. 